Article

\title{
Enantiomeric Variability of Distaminolyne A. Refinement of ECD and NMR Methods for Determining Optical Purity of 1-Amino-2-Alkanols
}

\author{
A. Norrie Pearce ${ }^{1}$, Brent R. Copp ${ }^{1}$ (D) and Tadeusz F. Molinski ${ }^{2,3, *(D)}$ \\ 1 School of Chemical Sciences, University of Auckland, Private Bag 92019, Auckland 1142, New Zealand; \\ n.pearce@auckland.ac.nz (A.N.P.); b.copp@auckland.ac.nz (B.R.C.) \\ 2 Department of Chemistry, University of California, San Diego, 9500 Gilman Drive MC0358, \\ La Jolla, CA 92093, USA \\ 3 Skaggs School of Pharmacy and Pharmaceutical Sciences, University of California, San Diego, 9500 Gilman \\ Drive MC0358, La Jolla, CA 92093, USA \\ * Correspondence: tmolinski@ucsd.edu; Tel.: +1-858-534-7115
}

Academic Editor: Maria Carla Marcotullio

Received: 11 December 2018; Accepted: 23 December 2018; Published: 27 December 2018

check for updates

\begin{abstract}
Sample configurations of distaminolyne A (1a); isolated from the ascidians Pseudodistoma opacum and P. cereum, and collected at different sites in New Zealand, were investigated by two methods: Exciton coupled electronic circular dichroism (EC ECD) of the corresponding N,O-dibenzoyl derivative $\mathbf{1} \mathbf{b}$; and chiral reagent derivatization of $\mathbf{1 a}$ with $(S)$ - and $(R)$ - $\alpha$-methoxyphenylacetic acid (MPA), followed by ${ }^{1} \mathrm{H}-\mathrm{NMR}$ analysis. Configuration and optical purity of $1 \mathrm{a}$ (\%ee) was found to vary depending on the geographic distribution of ascidian colonies. An improved method for preparing $\mathrm{N}, \mathrm{O}$-diarenoyl derivatives of $\mathbf{1 a}$ was optimized. The EC ECD method was found to be complementary to the MPA-NMR method at different ranges of \%ee.
\end{abstract}

Keywords: circular dichroism; amino alcohols; absolute configuration; marine natural products

\section{Introduction}

The natural products sphingolipids-characterized by homologs and highly-modified analogs of the canonical $\mathrm{C}_{18}$ long-chain base, D-erythro-sphingosine-are rare among plants and microbes, but prevalent in the diverse realm of marine invertebrates [1]. The most common variations are 2-amino-alkane-1,3-diols and their $\Delta^{4}$-unsaturated derivatives, corresponding to $\mathbf{1}$ and D-erythro-4,5-dihydrosphingosine (sphinganine). Other variations include long-chain aminoalkanols (AAs), including 1-amino-2-alkanols (1-AAs), 2-amino-3-alkanols (2-AAs), and compounds that may be related to the latter through divergent biosynthetic pathways (e.g., long-chain $2 \mathrm{H}$-azirines [2]). Many AAs are biologically active; for example, the simple homolog spisulosine from the clam Spisula polynyma inhibits cell proliferation by disassembly of actin stress filaments [3].

Unlike sphingosine, AA configurations are heterogeneous: The relative configuration (RC) and absolute configuration (AC) of 2-AAs vary from species to species. Configuration assignment to AAs is deceptively simple, and confounded by weak specific rotations that have been misinterpreted in the past leading to erroneous assignments [4], or no assignment, which defer the problem to total synthesis $[5,6]$. A single chirogenic center in 1-AAs is responsible for $[\alpha]_{D}$ with magnitudes within a narrow range of $\sim \pm 1-3$; for example, in S-distaminolyne $\mathrm{A}\left(1 \mathbf{a},[\alpha]_{\mathrm{D}}-1\right), \mathrm{C}_{17} \mathrm{AA}$ from the New Zealand ascidian Pseudodistoma opacum [7]. The configuration of $\mathbf{1 a}$ was assigned from interpretation of exciton coupling observed in the electronic circular dichroism ECD spectrum of the corresponding $\mathrm{N}, \mathrm{O}$-dibenzoyl derivative $\mathbf{1 b}$ [7] according to an extension of the exciton coupling circular dichroism 
(EC ECD) dibenzoate method pioneered by Nakanishi and Harada [8]. Prior to this report, the EC ECD method was applied successfully to $\mathbf{2} \mathbf{b}$, the $\mathrm{N}, \mathrm{O}$-dibenzoyl derivative of an unnamed 1-AA natural product; 2a, from a didemnid ascidian collected on the Great Barrier Reef [9].

The configuration of (S)-1a was recently challenged by Sun et al. and 're-assigned' as $R$ based on a total synthesis of $(S)$ - and (R)-1a, and the comparison of specific rotations-albeit of low magnitudes-with the published value of the natural product [10]. Paradoxically, a subsequent synthesis of 1a by Dumpala et al. using different methodology, upheld the original $2 S$ stereoassignment [11]. Notably, the validity of the EC ECD method used for the original assignments of $\mathbf{1 b}$ [7] or $\mathbf{2} \mathbf{b}$ [9] was not disputed—in fact, not even addressed —in either report, leaving a dilemma: which assignment is correct?

Upon revisiting the original assignment, we found the assignment of AC of (S)-1a was upheld by careful re-examination of the ECD data, and new comparisons to model 1-AAs, (S)-3a, and (R)-3b prepared by rational asymmetric synthesis, and converted to dibenzoyl derivatives $\mathbf{4 a}, \mathbf{b}$ [12]: The ECD spectrum of (S)-1/b was essentially the same as that of (S)-4a. An elementary lesson in chiroptical analysis, reprised here, is that reassignment of natural products based solely on comparisons of $[\alpha]_{\mathrm{D}}$ of weakly rotatory compounds is tenuous, at best, and unsupportable in light of stronger counter-evidence; for example, assignments based on the non-empirical interpretation of EC ECD [8].

In this report, we investigate chiroptical properties of additional acylates of 1-AAs, the curious chain-length dependence of diacylation reactions under standard conditions, and improved methods for preparing $\mathbf{1 b}$ and related acylates. We also found configurational variability of 1a isolated from samples of P. opacum and P. cereum collected at different sites from the North Island of New Zealand, and outline complementary methods for measuring AC and enantiomeric excess (\%ee) of 1a by ECD of bis-arenoyl derivatives, and ${ }^{1} \mathrm{H}-\mathrm{NMR}$ after conversion with a chiral derivatizing agent (CDA).

\section{Results}

Unlike acylation of 2-AAs, benzoylation of 1-AAs with BzCl-pyridine has delivered variable success, giving the desired dibenzoyl derivatives in low yields. For example, benzoylation of $\mathbf{1 a}$ (Figure $1 \mathrm{~b}$; Method A: $\mathrm{BzCl}, 4$ equiv, DMAP, pyridine, $50{ }^{\circ} \mathrm{C}, 64 \mathrm{~h}$ ), gave $\mathbf{1 b}$ in only $8 \%$, but a larger amount (16\%) of the mono-acylated $N$-benzamide, even with excess equivalencies of reagents [7]. Similar yields were obtained for model compounds (S)-3a and (R)-3b, giving (S)-4a (15\%) and $(R)-4 \mathbf{b}(25 \%$; [12]). From earlier work, alternative conditions for benzoylation ( $N$-benzoylimidazole, $\mathrm{DBU}, \mathrm{CH}_{3} \mathrm{CN}, 60{ }^{\circ} \mathrm{C}$ [13]) applied to (2S,3R)-2-amin ododecan-3-ol, from Clavelina oblonga [14] or sphingolipids [15], were also less than satisfactory. Although it is certain that benzoylation of the amino group occurs as the first step, it was not clear why benzoylation of the secondary $\mathrm{OH}$ of the benzamide intermediate was so sluggish. One possibility is formation of micelles in the dipolar solvents pyridine, and $\mathrm{CH}_{3} \mathrm{CN}$ that retard the second benzoylation step (see below).

(a)

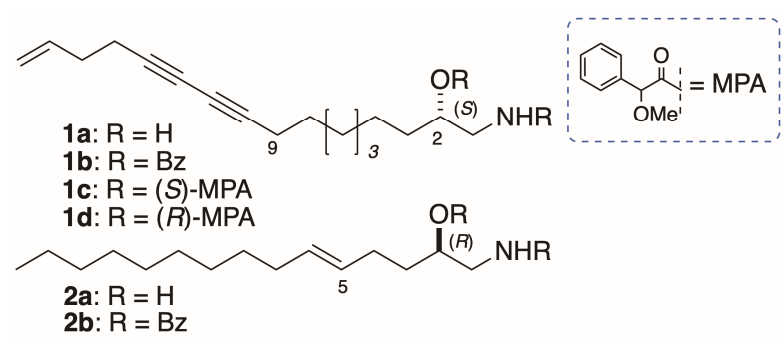

(b)

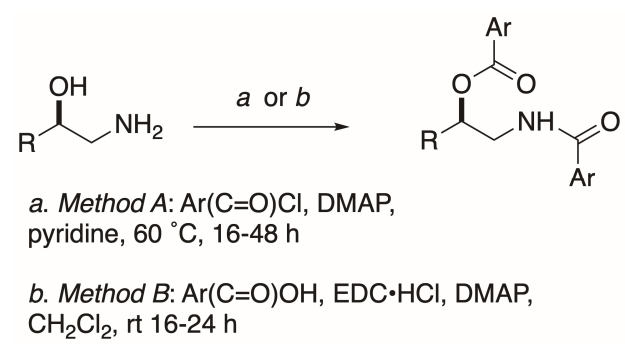

Figure 1. (a) Distaminolyne A (1a; [7]) and un-named 1-AA natural product (2a; [9]) and their corresponding acylates, $\mathbf{1} \mathbf{b}-\mathbf{d}$ and $\mathbf{2} \mathbf{b}$. (b) Two methods for acylation of 1-AAs. 


\subsection{Acylation of Model Compounds}

In order to investigate the chain-length dependence and byproduct, we explored the acylation of homologous 1-AAs: The $C_{10}$ compounds (S)-3a and (R)-3b (Figure 2), and the $C_{6}$ and $C_{4}$ homologs $(R)-5 \mathbf{b}$ and (S)-6a, respectively. Naphthoylation of $(R)-\mathbf{4 b}$ (Method A) gave mono $N$-naphthamide $7 \mathbf{b}$ (Figure $2 \mathrm{~b})$ as the major product $(18 \%)$, and smaller amounts of oxazoline $8\left[0.4 \%,[\alpha]_{\mathrm{D}}+2.6(c) 0.5\right.$, $\left.\mathrm{CHCl}_{3}\right)$ ], and the di-N,O-naphthoyl derivative $(\mathrm{R})-9 \mathbf{b}(0.5 \%)$. Cyclodehydration of AA benzamides is known to occur with inversion of configuration at C-2 under certain conditions that activate the secondary $\mathrm{OH}$ group (e.g., Brønsted acid, $\mathrm{SOCl}_{2}$ ) for intramolecular nucleophilic $S_{\mathrm{N}} 2$ displacement by the carboxamide oxygen $[16,17]$. Clearly, if a similar inversion was occurring at C-2 during formation of $\mathbf{1 b}$ under elevated temperature and prolonged reaction times of Method $\mathrm{A}$, it would undermine the validity of the ECCD assignment method for all 1-AAs. Likewise, if oxazolines were the intermediates on the pathway to $\mathbf{4 a}, \mathbf{b}$, these model compounds would be invalid. In order to test this hypothesis, benzoylation of $(R)-3 \mathbf{b}$ was carried out under the milder conditions (Method B; see below). Gratifyingly, the product $(R)-4 b$ showed an essentially identical specific rotation $\left([\alpha]_{\mathrm{D}}^{23}-24.1(c 1.48, \mathrm{MeOH})\right)$ to that of $(R)-4 \mathbf{b}$ produced by Method $\mathrm{A}\left([\alpha]_{\mathrm{D}}^{23}-26.1(c\right.$ 1.78, $\left.\mathrm{MeOH}) ;[12]\right)$ eliminating the possibility of inversion at C-2 under the latter conditions.

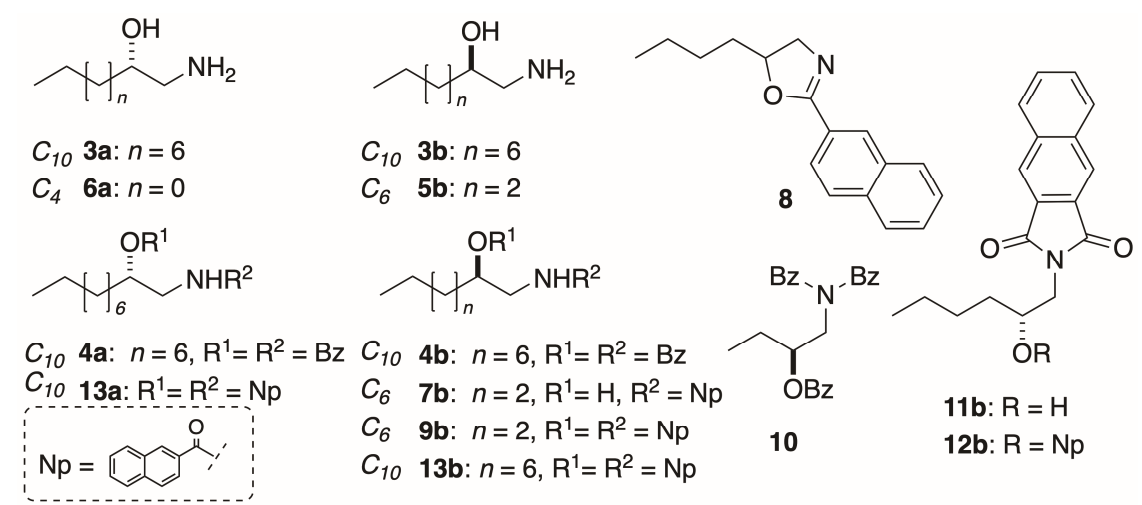

Figure 2. Model 1-amino-2-alkanols (1-AAs) 3-5 and their corresponding acylates.

Benzoylation of the shortest C4-chain 1-AA (S)-6a by Method A gave no dibenzoyl compound, but instead the $N, N, O$-tribenzoyl derivative $(S)-\mathbf{1 0 b}$ as the only identifiable product (5\%). Imide (S)-10b was deemed to be unsuitable for ECCD assignments due to the difficulty of establishing the directionality of the charge-transfer electronic transition dipole vectors of the three chromophores.

Eventually, a more reliable method for $\mathrm{N}, \mathrm{O}$-dibenzoylation of $\mathbf{1 a}, \mathbf{3} \mathbf{a}$, and $\mathbf{3} \mathbf{b}$ was deployed (Method B: EDC $\cdot \mathrm{HCl}$, benzoic acid, DMAP, 5 equiv. each, $\mathrm{CH}_{2} \mathrm{Cl}_{2}$, rt) that improved the yields of $\mathbf{1 b}$, 3a, and $3 \mathbf{b}(\sim 40 \%$-quant.) on a $\sim 1-3 \mathrm{mg}$ scale and suppressed acylation byproducts. For example, our earlier low yielding N,O-bis-(2-naphthoylation) of (S)-3b to $(R)-\mathbf{1 3 b}(9 \%$; [12]) was greatly improved by applying Method $B$ with replacement of 2-naphthoic acid for benzoic acid: The 1-AA (S)-3a was smoothly converted to (S)-13a in $46 \%$ yield.

A second approach for exciton coupling ECD analysis was evaluated based on Nakanishi's reported microscale derivatization of amino-polyols for 'picomole scale' assignment of sphingosine bases through introduction of two different well-behaved chromophores in separate steps [18,19]. Primary amine $(R)-\mathbf{5 b}$ was first converted to the naphthimide $(R)-\mathbf{1 1 b}$ (pyridine, DMAP, naphthalene-2,3-dicarboxylic acid anhydride, $110{ }^{\circ} \mathrm{C}$ ) in good yield $(74 \%)$, followed by separate O-naphthoylation (2-naphthoic acid, EDC, DMAP) to give the derivative $(R)-\mathbf{1 2 b}(72 \%)$. The CD spectra of the new chromophoric derivatives were measured and compared.

Method B was also adapted to sub- $\mu$ mole acylation of 1-AAs with modification of Nakanishi's approach employing melting point capillaries as reaction vessels $[18,19]$. Treatment of $5 \mathbf{b}(0.35 \mu \mathrm{mol}$; Method C) with a standard solution prepared from the reagents in DCE (2.8 equiv.; See Experimental) and heating $\left(45^{\circ} \mathrm{C}\right.$ or $67^{\circ} \mathrm{C}, 60 \mathrm{~min}$; Method $\mathrm{C}$ ) gave, after recovery and purification by preparative 
TLC, $(R)-\mathbf{1 2} \mathbf{b}$ in yields of $31 \%$ and $40 \%$, respectively (Calculated from measured absorbances at $\lambda_{\max }$ $231 \mathrm{~nm}(\mathrm{TFE})$ ).

\subsection{Circular Dichroism of Acylated 1-AAs}

Comparison of the ECD spectra of the three shorter chain chromophoric derivatives of 1-AAs showed significant differences in magnitude and complexity. The CD spectrum of naphthoyl naphthimide $(R)-\mathbf{1 2 b}$ (Figure 3a) displayed three major Cotton effects (CEs, $\lambda 216(\Delta \varepsilon+24.7), 240$ $(+25.8)$, and $259(-31.8))$ due to interaction of the 2-naphthoate charge-transfer (CT) band, likely with both the longitudinal CT band $\left({ }^{1} B_{\mathrm{b}}\right)$ and transverse bands $\left({ }^{1} L_{\mathrm{a}}\right.$, and $\left.{ }^{1} L_{\mathrm{b}}\right)$ of the naphthimide chromophore in a complex manner [18]. In contrast, the ECD spectrum of dinaphthoyl derivative $(R)-9 \mathbf{b}$ was relatively simple consisting of a split-Cotton effect (CE) at $\lambda 228(\Delta \varepsilon+53)$ and $244(-66)$ of large magnitude $(A=119)$ from the two degenerate ${ }^{1} B_{\mathrm{b}}$ CT bands.

(a)

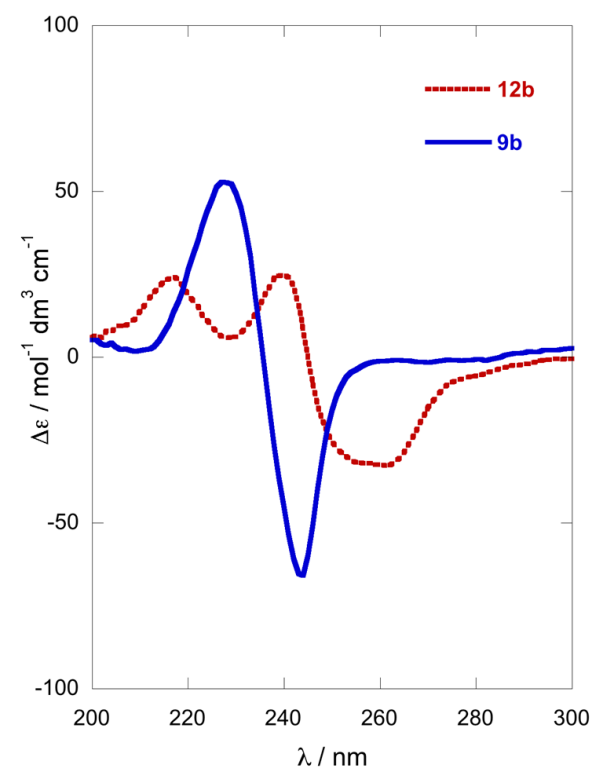

(b)

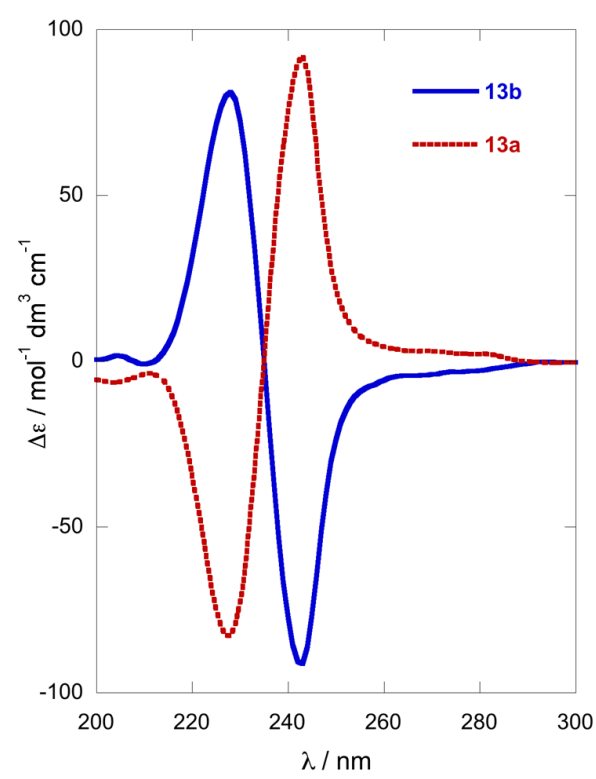

Figure 3. ECD spectra of: (a) (R)-9b (-) and (R)-12b (-) (TFE, $\left.23{ }^{\circ} \mathrm{C}\right)$; and (b) (S)-13a (this work) and $(R)-\mathbf{1 3 b}[12]\left(\mathrm{MeOH}, 23^{\circ} \mathrm{C}\right)$.

The ECD spectra of the (R)-N,O-bis-(2-naphthoyl) derivatives of $\mathrm{C}_{6}$ and $\mathrm{C}_{12}$ 1-AAs displayed ECD spectra of the same form (negative split $C E$ ), with only slight differences in magnitudes (Figure $3 a, b)$. Compared to the longer $\mathrm{C}_{10}$ chain compound $(R)-\mathbf{1 3 b}(A=172, A$ is defined as the difference of $\Delta \varepsilon$ measured from trough to crest in the split-CE [8], $\mathrm{MeOH}$ [12], Figure 3b), the $\mathrm{C}_{6}$ homolog $(R)-9 \mathrm{~b}$ was about 30\% less intense when measured in 2,2,2-trifluoroethanol (TFE, $A=119$; Figure 3a), but essentially within the expected range.

\subsection{Enantiomeric Purity of $\mathbf{1} \boldsymbol{a}$-Geographic Variation}

We examined the optical purity of 1 a from various samples of P. opacum and one of P. cereum, collected respectively from Whangateau Harbor and Princes Island, North Island of New Zealand, by conversion to the $\mathrm{N}, \mathrm{O}$-dibenzoate $\mathbf{1} \mathbf{b}$, and measurement of their ECD spectra and calculation of \%ee by comparison with $\mathrm{CE}$ data observed for model compound $\mathbf{4} \mathbf{b}$ (Table 1). To our surprise, a re-collection of P. opacum from the same location as reported previously [7] (Entry 4), which revealed that unlike the original collection, the newer sample of 1a was nearly racemic (Table 1, Entry 5; Figure 4a). It was noted that this new collection of P. opacum contained a mixture of two ascidian color-morphs; white and beige, which could possibly have some bearing on the configurational hetereogeneity of $1 \mathbf{a}$. 
Consequently, another collection of ascidian material was undertaken, taking care to separate the two color-morphs. Analysis of 1a from these two color-morphs (entries 1 and 2; Figure 4b) revealed that both samples were also nearly racemic with \%ee within experimental error. It appeared that none of the collections of P. opacum from that same location in the same season contained 1a of high optical purity. Similar ECD analysis of the dibenzoyl derivative of 1a isolated from specimens of P. cereum collected at Princes Island (Entry 3 ) identified the natural product as a scalemic mixture ( 49\%ee) of predominantly (S)-configuration (Figure 4 b).

Table 1. Optical Purities of N,O-Dibenzoyl Derivatives of $1 \mathbf{a}^{1}-3 \mathbf{a}$ by ECD and CDA Methods.

\begin{tabular}{|c|c|c|c|c|c|c|c|c|c|}
\hline Entry & Compounds & $\begin{array}{l}\text { Specimen } \\
\text { Code }\end{array}$ & $\begin{array}{c}S / R \\
\text { ECD }\end{array}$ & $A^{2}$ & $\begin{array}{c}\% \text { ee } \\
{ }^{2} \text { ECD }\end{array}$ & $\begin{array}{c}\% \text { ee }{ }^{3} \\
(S)-\text { MPA }\end{array}$ & $\begin{array}{c}\% \mathrm{ee}^{4} \\
(R)-\mathrm{MPA}\end{array}$ & $\begin{array}{l}\% \text { ee } \\
\text { MPA }\end{array}$ & Ref. \\
\hline 1 & $1 \mathrm{a}$ & NP-12-8-1 & & $\sim 0$ & $\sim 0$ & $4(S)$ & $20(S)$ & $12(S)$ & 6 \\
\hline 2 & 1a & NP-12-9-1 & & $\sim 0$ & $\sim 0$ & $2(R)$ & $32(S)$ & $15(S)$ & 6 \\
\hline 3 & $1 a^{7}$ & NP-12-10-1 & $S$ & 5 & 49 & $26(S)$ & $42(S)$ & $34(S)$ & 6 \\
\hline 4 & 1a & JW-4-51-5 & $S$ & 12.7 & $\sim 100$ & - & - & - & 6 \\
\hline 5 & 1a & NP-9-161-3 & $R$ & 0.33 & 2.9 & $2(R)$ & $10(S)$ & $4(S)$ & 6 \\
\hline 6 & $2 a^{8}$ & $90-06-045$ & $R$ & 15.3 & - & - & - & - & [9] \\
\hline 7 & $4 a$ & - & $S$ & 10.9 & $>97^{9}$ & $>99(S)$ & - & - & [12] \\
\hline 8 & $4 b$ & - & $R$ & 11.4 & $>97^{9}$ & - & - & - & [12] \\
\hline
\end{tabular}

\footnotetext{
${ }^{1}$ Natural samples of 1a, isolated from Pseudodistoma opacum, collected at Ti Point, North Island, New Zealand, were converted to N,O-dibenzoyl derivative $\mathbf{1 b}$ by Method $B$ as described in the Experimental. ${ }^{2}$ See footnote on previous page for the definition of $A$.\%ee ECD calculated from $100 \times A(\mathbf{1 b}) / A(\mathbf{4 b}) .{ }^{3}(S)$ - and $(R)$ - $\alpha$-methoxyphenylacetic (MPA) derivatives prepared by Method B [12]. \%ee calculated from integral ratio of $\mathrm{C} \alpha-\mathrm{H}^{1} \mathrm{H}-\mathrm{NMR}$ resonances of bis-(S)-MPA derivative. ${ }^{4} \%$ ee calculated from integral ratio of $\mathrm{C} \alpha-\mathrm{H}^{1} \mathrm{H}$-NMR resonances of bis-(R)-MPA derivative. ${ }^{5}$ Average of $(S)$ - and (R)-MPA \%ee values. ${ }^{6}$ This work. ${ }^{7}$ From P. cereum. ${ }^{8} \mathbf{2 a}$, from an unidentified didemnid ascidian collected on the Great Barrier Reef, was converted to $\mathbf{2 b}$ using a variant of Method A [9]. ${ }^{9}$ Optical purity from (S)-1,2-epoxydecane ( $>97 \%$ ee), prepared from the Jacobsen's hydrolytic kinetic resolution (HKR) reaction, and used in the synthesis of (S)-4a.
}

(a)

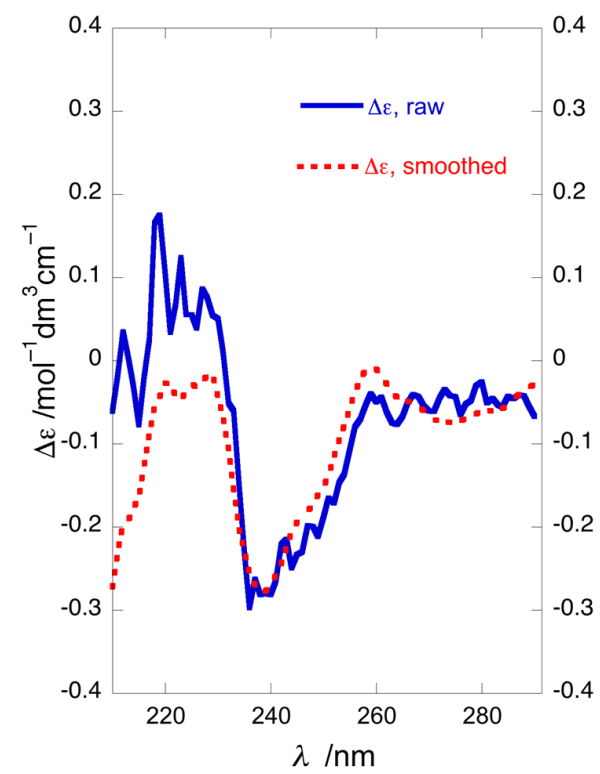

(b)

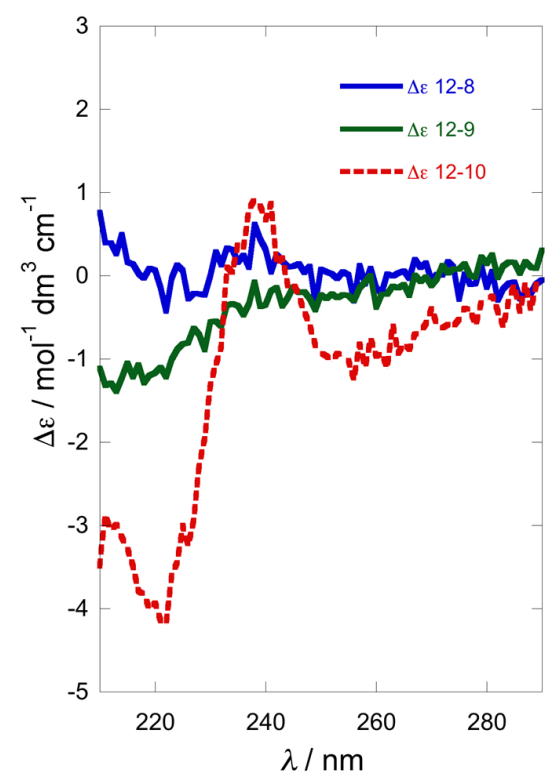

Figure 4. $\mathrm{ECD}$ of $\mathbf{1 b}\left(\mathrm{MeOH}, 23^{\circ} \mathrm{C}\right)$ : (a) 'near racemic' (R)-1b (blue) and fitted curve (red); (b) overlay of three samples of $\mathbf{1 b}$ prepared from $\mathbf{1 a}$ collected at different locations (Table 1 ).

To further investigate the enantiopurity of samples of 1a we prepared CDA derivatives using the $\alpha$-methoxyphenylacetic acid (MPA) method of Riguera [20]. EDC-promoted coupling of 1a with either $(S)$ - or $(R)$-MPA afforded bis-(N,O)-MPA derivatives $1 \mathrm{c}$ and $\mathbf{1 d}$, respectively.

In order to avoid possible introduction of bias to the ratio of diastereomeric products through fractionation during column chromatography, the crude CDA derivatization products were evaluated 
directly by ${ }^{1} \mathrm{H}-\mathrm{NMR}$ (see Supporting Information). While contaminant signals overlapped the ${ }^{1} \mathrm{H}-\mathrm{NMR}$ OMe resonances $\left(\delta_{\mathrm{H}} 3.23-3.40\right)$, the $\mathrm{C} \alpha \mathrm{H}$ region $\left(\delta_{\mathrm{H}} 4.40-4.80\right)$ was relatively un-obscured and so used for evaluation of enantiopurity. The MPA derivatives of synthetic (S)-1a prepared by Sun et al., identified $\mathrm{C} \alpha \mathrm{H}$ resonances at $\delta_{\mathrm{H}} 4.80$ (S-MPA ester), $\delta_{\mathrm{H}} 4.71$ (R-MPA ester), $\delta_{\mathrm{H}} 4.59$ (R-MPA amide), and $\delta_{\mathrm{H}} 4.40$ (S-MPA amide) $\left(\mathrm{CDCl}_{3}\right)$ [10]. The MPA derivatives of synthetic $(S)$-3a displayed a single pair of $\mathrm{C} \alpha \mathrm{H}$ resonances (>99\%ee; Figure S21, see Supplementary Material), and application of the configurational model [20] confirmed the AC (Table 1; Entry 7). In the case of 1a sourced from P. cereum, ${ }^{1} \mathrm{H}-\mathrm{NMR}$ spectra of both MPA-derivatized samples 1c and 1d displayed the presence of all four $\mathrm{C} \alpha \mathrm{H}$ resonances, showing that 1a (Figure S22) was a mixture of enantiomers favoring an excess of $S$ (42\%ee) when quantified using 1c, or 26\%ee for 1d (average of 34\%ee). The optical purities of 1a samples obtained from other collections of P. opacum were evaluated in a similar manner (Entries 1, 2 and 5); in each case very low \%ee values were observed (data not shown).

\section{Discussion}

\subsection{Variable Acylation Efficiency of Long-Chain 1-AAs}

The unexpected chain-length dependence of benzoylations or naphthoylations of 1-AAs under conventional conditions (e.g., Method A) suggests subtle differences in solution phase that amplify to larger differences in rates of reaction for the second reaction step: The acylation of the secondary $\mathrm{OH}$ group. It should be stressed that diacetylation of 1-AAs does not suffer these dramatic changes: Diacetylation reactions of long-chain 1-AAs under standard conditions (neat 1:1 pyridine-acetic anhydride as solvent and reactant) were unimpeded and high-yielding [12] as expected with the more reactive acylation reagent and larger over-equivalencies. We presume the uniform success of acylation of long-chain 1-AAs under the conditions of Method B avoids micelle formation when carried out in solvents of lower dielectric constant (e.g., $\mathrm{CH}_{2} \mathrm{Cl}_{2}$ or DCE) than pyridine.

\subsection{The EC ECD Conformational Model is Upheld}

Interpretation of the EC ECD spectra of $\mathbf{1 b}$ and $\mathbf{2} \mathbf{b}$ are based on Nagai's observations of the sign of the split CE and conformation analysis of (S)-14, the simplest chiral homolog of an N,O-dibenzoyl-1-AA (Figure 5) [21]. Of the three dominant gauche conformers, $i$ is disfavored by steric hindrance. Conformer $i i$ is expected to show $\Delta \varepsilon \sim 0$ due to the antiperiplanar arrangement of the transition dipole moments of the two Bz chromophores, leaving iii as the favored conformer with the positive helicity inducing a negative split CE. The measured ECDs of the homologs $\mathbf{4 b}, \mathbf{9 b}$ and $\mathbf{1 3} \mathbf{a}, \mathbf{b}$ in this study all conform to this fundamental model; $S$ enantiomers correlate with positive split-CE and $R$ enantiomers correlate with a negative split CE. The strongest CEs in the series are observed by replacement of the Bz chromophore with 2-naphthoyl group (viz. 9a,b and 13a,b; [12]); consequently, introduction of the latter chromophore is preferred for stereoanalysis of natural 1-AAs.

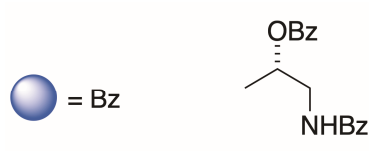

(S)-14

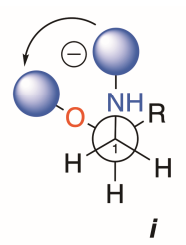

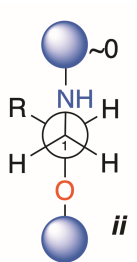

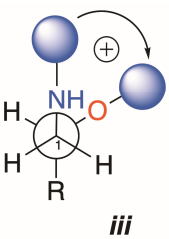

Figure 5. Model compound (S)-14, its most stable conformations (i-iii), and prediction of sign of the split-Cotton effect (CE, after Kawai et al. [21]. See also [8]; p. 159).

Finally, the naphthoyl-naphthimido derivatives, while well-served for 'fingerprinting' threo and erythro isomers of 2-amino-1,3-diols such as sphingosines and dihydrosphingosines [18,19], offer no advantage over a simple di-naphthoyl derivative (e.g., $\mathbf{9 b}$ or $\mathbf{1 3 a} \mathbf{3} \mathbf{b})$ for assignments of 1 -AAs; the 
latter derivatives offers simplicity, exceptional sensitivity combined with ease of preparation and interpretation of their ECD spectra.

\subsection{Semi-Quantitative Comparison of ECD and CD methods for Stereoassignment of 1-AAs}

The value of \%ee, defined by a ratio (Equation (1)) of the sum and difference of concentrations, $C$, of $(+)$ - and (-)-enantiomers, is prone to errors of measurement in each. Comparisons of $[\alpha]_{D}$ for sample and standard have long been used for determinations of \%ee, but they become flawed when the magnitudes of the specific rotations are low, or when sample solutions of different concentrations induce non-linearity. The complementarity of the two methods used in this work-ECD and CDA derivatization with MPA-for establishing \%ee and AC of 1-AAs, such as 1a, is apparent from a simple semi-quantitative analysis of the sources of error and observation of the discrepancies between the two methods (Table 1). The ECD method is best suited for \%ee of near-racemic samples where the null point corresponds to a racemate $\left(\Delta \varepsilon_{\text {sample }} / \Delta \varepsilon_{\text {standard }}=0\right)$. The sign and magnitude of non-zero split-CE signal ( $\sim 4 \%$ ee and higher) indicate configuration and non-racemic mixtures, respectively, with errors in the latter associated only with absolute $A$ values and the signal-to-noise of the measurement.

$$
\% \text { ee }=\frac{[C(+)-C(-)] \times 100}{[C(+)+C(-)]}=\frac{[\alpha]_{\mathrm{D} \text { sample }} \times 100}{[\alpha]_{\mathrm{D} \text { standard }}}=\frac{\Delta \varepsilon_{\text {sample }} \times 100}{\Delta \varepsilon_{\text {standard }}}
$$

EC ECD of vicinal $N, O$-di-arenoyl derivatives has two advantages over $[\alpha]_{D}$ for determination of \%ee: $\Delta \varepsilon$ is a molar quantity that conforms to the Beer-Lambert law and the absolute magnitude of the $\Delta \varepsilon$ signal (or $A$ ) is typically larger. Consequently, EC ECD is preferred for AC determination and quantitation of \%ee, but there are limitations. Errors in \%ee will be larger for samples near $100 \%$ ee where the ratio is obtained from $\Delta \varepsilon_{\text {sample }}$ and $\Delta \varepsilon_{\text {standard }}$ values that differ little in magnitude. MPA-derivatization-although requiring the preparation of separate $S$ - and $R$-derivatives-is equally reliable for assigning AC of 1a. For optical purity, however, the MPA method is better suited for measurements within a different range of \%ee values (closer to $50 \%$ ee) where cumulative bias in integral measurement $(C(+)$ or $C(-))$ due to instrumental factors (e.g., absolute error of integrals, partial NMR signal saturation, poor $\mathrm{S} / \mathrm{N}$ and non-linear error propagation) is lowest.

\subsection{Geographic Variation of $\mathbf{1 a}$}

The finding of heterogeneous enantiomeric compositions of different samples of $1 \mathbf{a}$ is unusual, and suggestive of a biosynthesis from lipid and amino acid precursors that differs from conventional long-chain base biosynthesis at one or more later steps. The proposed biosyntheses of 1-AA natural products (Figure 6a) is modeled on sphinganine-mycotoxin biosynthesis [22] with parallels to mammalian sphingosine biosynthesis (Figure $6 b$ ) [1]: Condensation of the $\mathrm{C}_{16}$ palmitoyl CoA ester with Ser, with concomitant decarboxylation, gives ketosphingosine (15) that undergoes stereospecific reduction of the keto group by NADPH and subsequent oxidative desaturation (Strictly, desaturation occurs on the corresponding ceramide, and free D-erythro-sphingosine is released through the action of a ceramidase ([1] p. 1622])) to give (2S,3R)-sphingosine.

(a)
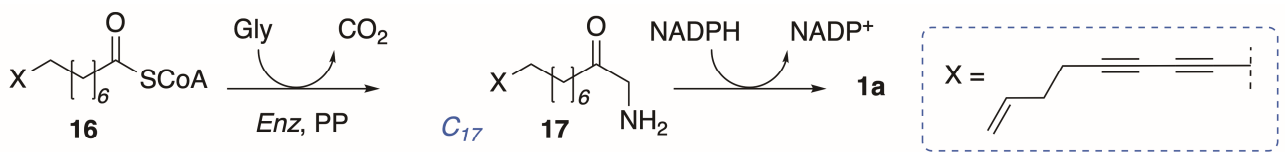

(b)
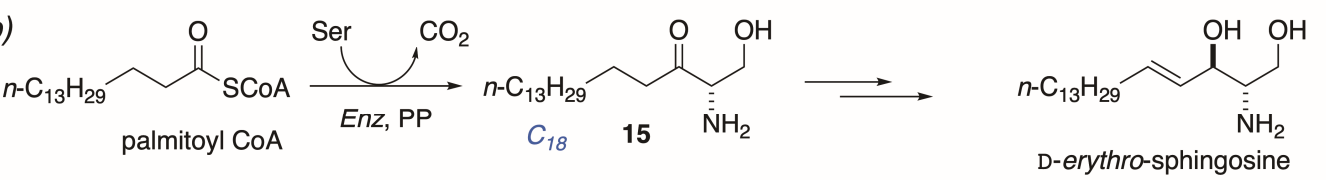

Figure 6. Hypothetical origin of (a) distaminolyne A (1a) modelled on (b) the known biosynthesis of D-erythro-sphingosine ([1]; p. 1622) and sphinganine-mycotoxins [22]. PP = pyridoxal 5' -phosphate. 
The latter sequence is highly conserved in higher animals: All mammalian sphingosines, including variants with different chain-lengths, are of the D-configuration. By comparison, the proposed biosynthesis of 1a would appear to proceed by activation of a hypothetical long-chain diyne-ene $\mathrm{C}_{17}$ fatty acid CoA ester 16, followed by decarboxylative condensation with Gly instead of Ser, and reduction of the resultant ketone 17 by NADPH. Unlike 15, the proposed intermediate aminoketone 17 undergoes reduction with lower stereofidelity than reduction of $\mathbf{1 5}$. In contrast, all natural 2-AAs appear to be biosynthesized with hallmark high stereofidelity even when the relative and absolute configurations differ from species to species [23].

\subsection{Broader Implications}

The foregoing results should have broader applications to both stereochemical analysis of other aminoalkanols from Nature and synthesis. While reliable, prior analyses of 2-AAs exploiting ECD of bis-N,O-dibenzoyl derivatives (e.g., halisphingosines; [15]) suffered the same problem of lower-than desirable yields. The corresponding bis-N,O-di-(2-naphthoyl) derivatives, prepared by Method B, should ameliorate problems of compound yield and even permit sub-nanomole analyses (e.g., Method C) on vanishingly small sample sizes. In the asymmetric syntheses of 1-AAs and 2-AAs, the challenges of determination of \%ee can better be met by ECD, or CDA derivatization and NMR; methods that nicely overcome the limitations imposed by sole reliance on comparisons of $[\alpha]_{D}$.

\section{Materials and Methods}

All UV-vis and chiroptical measurements were made with solutions prepared in spectroscopic grade solvents; $\mathrm{MeOH}, \mathrm{CHCl}_{3}$ (stabilized with amylenes) or $\mathrm{CF}_{3} \mathrm{CH}_{2} \mathrm{OH}$ (TFE), purchased from Acros Organics (NJ, USA). Optical rotations were recorded on a JASCO P2000 digital polarimeter (Easton, MD, USA) at the D-line of Na emission on solutions in quartz cells ( $0.100 \mathrm{dm}$ pathlength). UV-visible spectra were recorded on a JASCO V630 dual beam spectrometer (Easton, MD, USA) in quartz cuvettes (1.00 cm or $0.100 \mathrm{~cm}$ pathlength). Electronic circular dichroism spectra were recorded on either a Jasco J810 spectropolarimeter (Easton, MD, USA) or an Applied PhotoPhysics Chirascan with solutions in quartz cells $(0.100$ or $0.500 \mathrm{~cm})$. HRMS were acquired on two instruments: a Bruker micrOTOF Q II mass spectrometer (Billerica, MA, USA) using external calibration of sodium formate clusters, and an Agilent 6230 TOFMS (Santa Clara, CA, USA) with a Jetstream electrospray ionization source, calibrated by using Agilent ESL-L Low Concentration Tuning Mix (Part number G1969-85000, Agilent Technologies). ${ }^{1} \mathrm{H}-\mathrm{NMR}$ spectra were recorded at $500.16 \mathrm{MHz}$ on a Jeol ECA 500 spectrometer, at 399.91 MHz on a Mercury 400, at 400.13 MHz on a Bruker Avance AVIII $400 \mathrm{MHz}$ or at $500.19 \mathrm{MHz}$ on a Bruker Avance AVIII-HD $500 \mathrm{MHz}$ spectrometer (Billerica, MA, USA). ${ }^{13} \mathrm{C}-\mathrm{NMR}$ spectra were recorded at $125.69 \mathrm{MHz}$ on a Varian VX 500 spectrometer (Palo Alto, CA, USA) equipped with an Xsens ${ }^{13} \mathrm{C}\left\{{ }^{1} \mathrm{H}\right\}$ cryoprobe. Spectra were referenced to solvent (residual $\mathrm{CHCl}_{3} \delta 7.26 \mathrm{ppm} ; \mathrm{CDCl}_{3}$, $\delta 77.16$ ppm; residual $\mathrm{CHD}_{2} \mathrm{OD} \delta 3.31$ ppm; $\mathrm{CD}_{3} \mathrm{OD} \delta 49.00 \mathrm{ppm}$ ). Dry pyridine was distilled from $\mathrm{CaH}_{2}$ under an atmosphere of $\mathrm{N}_{2}$, and dry $\mathrm{CH}_{2} \mathrm{Cl}_{2}, \mathrm{CH}_{3} \mathrm{CN}$ were obtained by passage through commercial basic alumina cartridges under an atmosphere of Ar. Jacobsen's catalysts [24] $(S, S)-(+)-$ and $(R, R)-(-)-N, N^{\prime}$-bis(3,5-tert-butylsalicylidene)-2,2cyclohexanediaminecobalt(II), ( \pm )-1,2-epoxybutane and $( \pm)$-1,2-epoxyhexane were obtained from Sigma-Aldrich (Milwaukee, WI, USA).

Animal material. The ascidian consisting of mixed color-morphs of Pseudodistoma opacum was collected on September 29, 2017, at a depth of 4-6 m in Whangateau Harbour entrance $\left(36.3196^{\circ}\right.$ S, $\left.174.7831^{\circ} \mathrm{E}\right)$, Northland, New Zealand and kept frozen until used. The white and beige color-morphs were collected separately from the same location on November 14, 2017 and kept frozen until used. A voucher specimen of the ascidian is held at NIWA, Wellington, New Zealand as MNP 99203. The organisms were collected under MPI/UoA special permit 549. The sample of P. cereum was collected on November 24, 2002, at a depth of $15 \mathrm{~m}$ from Princes Island $\left(34.1786^{\circ} \mathrm{S}, 172.0418^{\circ} \mathrm{E}\right)$, Three Kings island group, Northland, New Zealand and kept frozen until used. A voucher specimen of P. cereum is held at NIWA as MNP7042. 
Isolation and purification. The freeze-dried ascidians were macerated and cold extracted with $\mathrm{MeOH}(4 \times 200 \mathrm{~mL})$, and the extract filtered, concentrated in vacuo affording a green solid, which was subjected to repeated $\mathrm{C}_{18}$ reversed-phase column chromatography using a gradient of $\mathrm{H}_{2} \mathrm{O}(0.05 \%$ TFA) to $100 \% \mathrm{MeOH}$. Distaminolyne A.TFA salt eluted with $70 \% \mathrm{MeOH} / \mathrm{H}_{2} \mathrm{O}$ as a pale yellow gum.

Distaminolyne A (NP-9-161-3, P. opacum mixed colors; 1a): 30 mg, 0.08\% dry wt; $[\alpha]_{\mathrm{D}}^{20}+1.0$ (c $\left.1.0 \mathrm{MeOH}\right)$; The ${ }^{1} \mathrm{H}$ NMR spectrum $\left(\mathrm{CD}_{3} \mathrm{OD}, 500 \mathrm{MHz}\right)$ was identical with the published data [7]; (+)-HRESIMS $m / z 262.2163[\mathrm{M}+\mathrm{H}]^{+}$, (calcd. for $\left.\mathrm{C}_{17} \mathrm{H}_{28} \mathrm{NO}, 262.2165\right)$.

Distaminolyne A (NP-12-8-1, P. opacum white color-morph; 1a): $27 \mathrm{mg}, 0.2 \%$ dry wt; $[\alpha]_{\mathrm{D}}^{20}+1.9(c$ 0.73, MeOH); The ${ }^{1} \mathrm{H}$ NMR $\left(\mathrm{CD}_{3} \mathrm{OD}, 500 \mathrm{MHz}\right)$ spectrum was identical with the published data [7]; (+)-HRESIMS $m / z 262.2161[\mathrm{M}+\mathrm{H}]^{+}$, (calcd. for $\left.\mathrm{C}_{17} \mathrm{H}_{28} \mathrm{NO}, 262.2165\right)$.

Distaminolyne A (NP12-9-1, P. opacum beige color-morph; 1a): 7 mg, 0.1\% dry wt; $[\alpha]_{\mathrm{D}}^{20}-1.1$ (c 0.70 , $\mathrm{MeOH}) ;$ The ${ }^{1} \mathrm{H}$ NMR $\left(\mathrm{CD}_{3} \mathrm{OD}, 500 \mathrm{MHz}\right)$ spectrum was identical with the published data [7]; (+)-HRESIMS $m / z 262.2159[\mathrm{M}+\mathrm{H}]^{+}$, (calcd. for $\left.\mathrm{C}_{17} \mathrm{H}_{28} \mathrm{NO}, 262.2165\right)$.

Distaminolyne A (NP-12-10-1, P. cereum; 1a): $8.5 \mathrm{mg}, 0.04 \%$ dry wt; $[\alpha]_{\mathrm{D}}^{20}+1.5($ c $0.275, \mathrm{MeOH}) ;{ }^{1} \mathrm{H} \mathrm{NMR}$ $\left(\mathrm{CD}_{3} \mathrm{OD}, 500 \mathrm{MHz}\right)$ 8 5.89-5.83 (1H, m), 5.12-5.08 (1H, m), 5.06-5.03 (1H, m), 3.76-3.73 (1H, m), 3.03 $(1 \mathrm{H}, \mathrm{dd}, J=12.8,3.0 \mathrm{~Hz}), 2.77(1 \mathrm{H}, \mathrm{dd}, J=12.8,9.5 \mathrm{~Hz}), 2.35(2 \mathrm{H}, \mathrm{t}, J=6.6 \mathrm{~Hz}), 2.28-2.24(4 \mathrm{H}, \mathrm{m})$, 1.56-1.29 (12H, m); ${ }^{13} \mathrm{C}$ NMR (CD $\left.\mathrm{CDD}_{3} 125 \mathrm{MHz}\right) \delta$ 137.8, 116.3, 78.0, 77.1, 68.7, 66.7, 66.3, 46.1, 36.0, 33.7, 30.5, 30.1, 29.8, 29.5, 26.3, 19.6; (+)-HRESIMS m/z 262.2157 [M + H] $]^{+}$, (calcd. for $\mathrm{C}_{17} \mathrm{H}_{28} \mathrm{NO}_{\text {, }}$ 262.2165).

N,O-Dibenzoyl derivative 1b: Distaminolyne A 1a (NP-12-8-1) (3.7 mg, $14 \mu \mathrm{mol})$ was dibenzoylated with benzoic acid according to Method $B$ to obtain, after RP $C_{18}$ chromatography (1:9 water/methanol) dibenzoyl derivative 1b, $2.6 \mathrm{mg}(40 \%)$. $[\alpha]_{\mathrm{D}}^{20} 0$ (c 0.26, MeOH); UV (MeOH) $\lambda_{\max }(\log \varepsilon) 203(4.28)$, 228 (4.19), 267 (3.55), 282 (3.44); The ${ }^{1} \mathrm{H}$ NMR ( $\mathrm{CD}_{3} \mathrm{OD}, 500 \mathrm{MHz}$ ) spectrum was identical with the published data [7]; (+)-HRESIMS $m / z 492.2500[\mathrm{M}+\mathrm{Na}]^{+}$, (calcd. for $\mathrm{C}_{31} \mathrm{H}_{35} \mathrm{NNaO}_{3}, 492.2509$ ).

N,O-Dibenzoyl derivative 1b: Distaminolyne A 1a (NP-12-9-1) (2.5 mg, $10 \mu \mathrm{mol})$ was dibenzoylated with benzoic acid according to Method $B$ to obtain, after RP $C_{18}$ chromatography (1:9 water/methanol) dibenzoyl derivative 1b, $1.8 \mathrm{mg}(40 \%)$. $[\alpha]_{\mathrm{D}}^{20}-1.1$ ( $\left.0.18, \mathrm{MeOH}\right) ; \mathrm{UV}(\mathrm{MeOH}) \lambda_{\max }(\log \varepsilon) 204(4.05)$, 228 (3.98), 266 (3.31), 281 (3.17); The ${ }^{1} \mathrm{H}$ NMR (CD $\mathrm{CD}_{3} 400 \mathrm{MHz}$ ) spectrum was identical with the published data [7]; (+)-HRESIMS $m / z 492.2504[\mathrm{M}+\mathrm{Na}]^{+}$, (calcd. for $\mathrm{C}_{31} \mathrm{H}_{35} \mathrm{NNaO}_{3}, 492.2509$ ).

N,O-Dibenzoyl derivative 1b: Distaminolyne A 1a (NP-12-10-1) (3.5 mg, $13 \mu \mathrm{mol})$ was dibenzoylated with benzoic acid according to Method $B$ to obtain, after RP $C_{18}$ chromatography (1:9 water/methanol) dibenzoyl derivative 1b, $2.6 \mathrm{mg}(41 \%)$. $[\alpha]_{\mathrm{D}}^{20}+0.4\left(c\right.$ 0.26, MeOH); UV (MeOH) $\lambda_{\max }(\log \varepsilon) 205(4.34)$, 226 (4.23), 267 (3.70), 282 (3.59); The ${ }^{1} \mathrm{H}$ NMR (CD $\mathrm{CD}_{3}, 400 \mathrm{MHz}$ ) spectrum was identical with the published data [7]; (+)-HRESIMS $m / z$ 492.2504 [M + Na] $]^{+}$, (calcd. for $\mathrm{C}_{31} \mathrm{H}_{35} \mathrm{NNaO}_{3}, 492.2509$ ).

(S)-MPA derivative 1c: Distaminolyne A 1a (NP-9-161-3) (2.0 mg, $8 \mu \mathrm{mol})$ was treated with (S)-MPA according to Method $B$ to yield $3.4 \mathrm{mg}(80 \%)$ of crude product. ${ }^{1} \mathrm{H}$ NMR $\left(\mathrm{CDCl}_{3}, 500 \mathrm{MHz}\right)$ diagnostic $\mathrm{C} \alpha H$ resonances of bis-MPA: $\delta 4.79(0.96 \mathrm{H}, \mathrm{s}), 4.71(1 \mathrm{H}, \mathrm{s}), 4.59(1 \mathrm{H}, \mathrm{s}), 4.41(0.96 \mathrm{H}, \mathrm{s})$.

(R)-MPA derivative 1d: Distaminolyne A 1a (NP-9-161-3) (2.0 mg, $8 \mu \mathrm{mol})$ was treated with (R)-MPA according to Method $B$ to yield $2.4 \mathrm{mg}(56 \%)$ of crude product. ${ }^{1} \mathrm{H} \mathrm{NMR}\left(\mathrm{CDCl}_{3}, 500 \mathrm{MHz}\right)$ diagnostic $\mathrm{C} \alpha H$ resonances of bis-MPA: $\delta 4.79(0.81 \mathrm{H}, \mathrm{s}), 4.71(1 \mathrm{H}, \mathrm{s}), 4.59(1 \mathrm{H}, \mathrm{s}), 4.41(0.81 \mathrm{H}, \mathrm{s})$.

(S)-MPA derivative 1c: Distaminolyne A 1a (NP-12-8-1) $(2.0 \mathrm{mg}, 6 \mu \mathrm{mol})$ was treated with (S)-MPA according to Method $B$ to yield $3.6 \mathrm{mg}(84 \%)$ of crude product. ${ }^{1} \mathrm{H}$ NMR $\left(\mathrm{CDCl}_{3}, 400 \mathrm{MHz}\right)$ diagnostic $\mathrm{C} \alpha \mathrm{H}$ resonances of bis-MPA: $\delta 4.79(1 \mathrm{H}, \mathrm{s}), 4.71(0.93 \mathrm{H}, \mathrm{s}), 4.59(0.93 \mathrm{H}, \mathrm{s}), 4.41(1 \mathrm{H}, \mathrm{s})$. 
(R)-MPA derivative 1d: Distaminolyne A 1a (NP-12-8-1) $(2.0 \mathrm{mg}, 6 \mu \mathrm{mol})$ was treated with $(R)-\mathrm{MPA}$ according to Method B to yield $3.8 \mathrm{mg}(89 \%)$ of crude product. ${ }^{1} \mathrm{H}$ NMR $\left(\mathrm{CDCl}_{3}, 400 \mathrm{MHz}\right)$ diagnostic $\mathrm{C} \alpha H$ resonances of bis-MPA: $\delta 4.79(0.68 \mathrm{H}, \mathrm{s}), 4.71(1 \mathrm{H}, \mathrm{s}), 4.59(1 \mathrm{H}, \mathrm{s}), 4.41(0.68 \mathrm{H}, \mathrm{s})$.

(S)-MPA derivative 1c: Distaminolyne A 1a (NP-12-9-1) $(2.0 \mathrm{mg}, 6 \mu \mathrm{mol})$ was treated with (S)-MPA according to Method $B$ to yield $2.3 \mathrm{mg}(54 \%)$ of crude product. ${ }^{1} \mathrm{H} \mathrm{NMR}\left(\mathrm{CDCl}_{3}, 400 \mathrm{MHz}\right)$ diagnostic $\mathrm{C} \alpha H$ resonances of bis-MPA: $\delta 4.79(0.97 \mathrm{H}, \mathrm{s}), 4.71(1 \mathrm{H}, \mathrm{s}), 4.59(1 \mathrm{H}, \mathrm{s}), 4.40(0.97 \mathrm{H}, \mathrm{s})$.

(R)-MPA derivative 1d: Distaminolyne A 1a (NP-12-9-1) $(2.0 \mathrm{mg}, 6 \mu \mathrm{mol})$ was treated with $(R)-\mathrm{MPA}$ according to Method B to yield $3.5 \mathrm{mg}(82 \%)$ of crude product. ${ }^{1} \mathrm{H}$ NMR $\left(\mathrm{CDCl}_{3}, 400 \mathrm{MHz}\right)$ diagnostic $\mathrm{C} \alpha H$ resonances of bis-MPA: $\delta 4.79(0.51 \mathrm{H}, \mathrm{s}), 4.71(1 \mathrm{H}, \mathrm{s}), 4.59(1 \mathrm{H}, \mathrm{s}), 4.41(0.51 \mathrm{H}, \mathrm{s})$.

(S)-MPA derivative 1c: Distaminolyne A 1a (NP-12-10-1) (1.5 mg, $6 \mu \mathrm{mol})$ was treated with (S)-MPA according to Method B to yield $2.4 \mathrm{mg}(75 \%)$ of crude product. ${ }^{1} \mathrm{H} \mathrm{NMR}\left(\mathrm{CDCl}_{3}, 500 \mathrm{MHz}\right)$ diagnostic $\mathrm{C} \alpha \mathrm{H}$ resonances of bis-MPA: $\delta 4.79(1 \mathrm{H}, \mathrm{s}), 4.71(0.59 \mathrm{H}, \mathrm{s}), 4.60(0.59 \mathrm{H}, \mathrm{s}), 4.40(1 \mathrm{H}, \mathrm{s})$.

(R)-MPA derivative 1d: Distaminolyne A 1a (NP-12-10-1) (1.5 mg, $6 \mu \mathrm{mol})$ was treated with $(R)-\mathrm{MPA}$ according to Method $B$ to yield $2.8 \mathrm{mg}(88 \%)$ of crude product. ${ }^{1} \mathrm{H}$ NMR $\left(\mathrm{CDCl}_{3}, 500 \mathrm{MHz}\right)$ diagnostic $\mathrm{C} \alpha H$ resonances of bis-MPA: $\delta 4.79(0.4 \mathrm{H}, \mathrm{s}), 4.71(1 \mathrm{H}, \mathrm{s}), 4.60(1 \mathrm{H}, \mathrm{s}), 4.40(0.4 \mathrm{H}, \mathrm{s})$.

(R)-1-Amino-2-hexanol, 5b: 1-Amino-2-alkanols were prepared from the corresponding optically enriched 1,2-epoxides ( $>97 \%$ ee, prepared by Jacobsen's hydrolytic kinetic resolution of the corresponding racemic epoxide [24] with $(S, S)$ - or $(R, R)$-catalyst) by ammoniolysis using a variation of the published procedure for $\mathbf{4 a}, \mathbf{b}$ [12]. To an ice-cold, stirred solution of $(R)-1,2$-epoxyhexane $(82.7 \mathrm{mg}$, $0.83 \mathrm{mmol})$ in $\mathrm{EtOH}(3.0 \mathrm{~mL})$ contained in a $20 \mathrm{~mL}$ vial was added, dropwise, aqueous $\mathrm{NH}_{4} \mathrm{OH}(20 \%$ $v / v, 3.0 \mathrm{~mL}$ ). The vial was sealed tightly and heated at $60^{\circ} \mathrm{C}$ for $23 \mathrm{~h}$. The cooled contents of the vial were transferred to a round bottom flask and the volatiles removed under reduced pressure. The residue was taken up in $\mathrm{CHCl}_{3}$ and passed through plug of anhydrous $\mathrm{Na}_{2} \mathrm{SO}_{4}$ to give, after removal of solvent, amino alcohol (R)-5b as a straw yellow oil (210 mg, 58\%). Distillation (twice, Kügelrohr, $120-30{ }^{\circ} \mathrm{C} / 1 \mathrm{~mm} \mathrm{Hg}$ ) gave an analytically pure sample. ${ }^{1} \mathrm{H}$ and ${ }^{13} \mathrm{C}$ NMR and MS data for $(R)-5 \mathbf{b}$ matched the literature values [25].

(S)-1-Amino-2-butanol, 6a: The title compound was prepared from (S)-1,2-epoxybutane according to the above-described procedure for $\mathbf{5 b}$, with final purification by distillation (Kügelrohr, $130^{\circ} \mathrm{C} / 1 \mathrm{~mm} \mathrm{Hg}$ ) have an analytically pure sample. Colorless oil, $[\alpha]_{\mathrm{D}}^{20}+17\left(c \mathrm{c} .0, \mathrm{CHCl}_{3}\right)$, lit. $+7.3\left(c 1.0, \mathrm{CHCl}_{3}\right)[26] ;{ }^{1} \mathrm{H}$ NMR and ${ }^{13} \mathrm{C}$ NMR matched the literature values [26].

Acylation, Method A: A solution of 1-amino-2-alkanol (1-AA, 1 equiv), freshly distilled benzoyl chloride (4 equiv) and DMAP ( 1 crystal) in pyridine (1-AA concentration $\sim 0.1 \mathrm{M}$ ) was heated at $60{ }^{\circ} \mathrm{C}$ under an atmosphere of $\mathrm{N}_{2}$ for $24-48 \mathrm{~h}$. The volatiles were removed under high vacuum and the residue purified by elution $\left(\mathrm{CH}_{2} \mathrm{Cl}_{2}\right)$ through a plug of basic alumina, followed by flash chromatography (silica or $\mathrm{RPC}_{18}$ ) followed by HPLC (silica or RP $\mathrm{C}_{18}$ ) if required.

Acylation, Method B: A solution of benzoic or 2-naphthoic acid ( 1 mmol, 5 equiv), EDC $\cdot \mathrm{HCl}$ (5.5 equiv) and DMAP in $\mathrm{CH}_{2} \mathrm{Cl}_{2}$ was stirred at $0{ }^{\circ} \mathrm{C}$ for 20 min under $\mathrm{N}_{2}$. A solution of 1-AA in $\mathrm{CH}_{2} \mathrm{Cl}_{2}$ was (final concentration of 1-AA $\sim 0.01 \mathrm{M}$ ) and the mixture warmed to rt over $24 \mathrm{~h}$. Additional $\mathrm{CH}_{2} \mathrm{Cl}_{2}(20 \mathrm{~mL})$ was added and the mixture washed successively with equal volumes of $10 \% \mathrm{HCl}$, water, $\mathrm{NaHCO}_{3}$ (satd.) and $\mathrm{H}_{2} \mathrm{O}$. After drying $\left(\mathrm{Na}_{2} \mathrm{SO}_{4}\right)$, the volatiles were removed and the residue purified by flash chromatography (silica), followed by HPLC (silica or RP $\mathrm{C}_{18}$ ) if required.

Acylation, Method C: A standard solution was prepared by dissolving EDC. $\mathrm{HCl}(18.6 \mathrm{mg}$, $97 \mu \mathrm{mol})$, DMAP $(11.2 \mathrm{mg}, 97 \mu \mathrm{mol})$ and 2-naphthoic acid $(16.3 \mathrm{mg}, 95 \mu \mathrm{mol})$ in 1,2-dichloroethane (DCE, $820 \mu \mathrm{L}$; final concentration $0.13 \mathrm{M}$ in 2-naphthoic acid). A solution of 1-AA in DCE (6.1 $\mu \mathrm{g}, 7.5 \mu \mathrm{L}$, $0.35 \mu \mathrm{mol})$ and an aliquot of the standard solution $(7.5 \mu \mathrm{L}, 0.98 \mu \mathrm{mol}, 2.8$ equiv.) were transferred into a melting point capillary using a gas tight syringe which was then flame sealed. The capillary tube was placed into a melting point apparatus set at $68^{\circ} \mathrm{C}$ and left for $60 \mathrm{~min}$, after which the liquid contents of 
the tube were removed with a narrow capillary and applied directly onto a glass backed TLC plate (6 $\times 6 \mathrm{~cm}$, silica, $250 \mu \mathrm{m}$, prewashed by $2 \times$ development in 1:1 EtOAc/ $n$-hexane) in replicate lanes ( $n=$ 6). After development of the TLC plate in 1:4 EtOAc $/ n$-hexane, the fluorescent spots corresponding to the $\mathrm{N}, \mathrm{O}$-dinaphthoyl-1-AA product (for $(R)-\mathbf{1 2} \mathbf{b}, R_{\mathrm{f}} 0.20$ ) were scraped from the plate into a $6 \mathrm{~mL}$ vial containing a magnetic stir bar, and the mixture extracted with TFE $(1.0 \mathrm{~mL})$ by vigorous stirring for $30 \mathrm{~min}$. The vial was centrifuged and measurements of the UV-vis and ECD spectra were carried out directly on the supernatant (30-40\% yield based on absorbance at $\lambda_{\max } 231 \mathrm{~nm}$ ).

N,O-Dibenzoyl-1-amino-2-decanol (R)-4b: (R)-1-Amino-2-decanol (3b) $(2.5 \mathrm{mg}, 14 \mu \mathrm{mol})$ was dibenzoylated with benzoic acid according to Method $B$ to obtain, after 'pencil column' chromatography (silica, 1:3 EtOAc/ $n$-hexane) dibenzoyl derivative $(R)-4 \mathbf{b}$ (7.3 mg, quant). $[\alpha]_{\mathrm{D}}^{20}-24.1$ ( c 1.48, MeOH). lit -26.2 ( $c$ 1.78, MeOH) [12]. The ${ }^{1} \mathrm{H}-\mathrm{NMR}$ spectrum $\left(\mathrm{CDCl}_{3}\right)$ was identical with the published data [12].

Naphthoylation of Amino Alcohol (R)-5b: 2-Naphthoyl chloride (304 mg, $1.60 \mathrm{mmol}, 2.5$ equiv), freshly prepared from 2-naphthoic acid ( $\mathrm{SOCl}_{2}$, reflux), was added to a stirred solution of 1-AA $(R)-5 \mathbf{b}(75.3 \mathrm{mg}$, $0.64 \mathrm{mmol})$ and DMAP $(1$ crystal $)$ in pyridine $(5.0 \mathrm{~mL})$ under $\mathrm{N}_{2}$, and the mixture heated at $60^{\circ} \mathrm{C}$ for $96 \mathrm{~h}$. The volatiles removed under high vacuum and the pale pink semi-crystalline residue (220.4 $\mathrm{mg})$ was eluted through a plug of basic alumina with $\mathrm{CH}_{2} \mathrm{Cl}_{2}$. The residue obtained by removal of solvent was separated by flash chromatograph $\left(2: 98 \mathrm{MeOH} / \mathrm{CH}_{2} \mathrm{Cl}_{2}\right)$. The UV-absorbing fractions (TLC) were combined and, after removal of solvent, the residue was triturated with warm diethyl ether to give white crystals of mono-naphthamide $(R)-7 \mathbf{b}(29.5 \mathrm{mg}, 18 \%)$. The supernatant was concentrated and the residue $(4.3 \mathrm{mg})$ separated, first on a 'pencil column' $\left(1 \% \mathrm{MeOH} / \mathrm{CH}_{2} \mathrm{Cl}_{2}\right)$ followed by HPLC (silica, $5 \mu, 40: 60 \mathrm{EtOAc} / \mathrm{n}$-hexane, $\left.3.0 \mathrm{~mL} \cdot \mathrm{min}^{-1}\right)$ to give dinaphthoyl derivative $(R)-9 \mathbf{b}(1.2 \mathrm{mg}, 0.5 \%)$ and

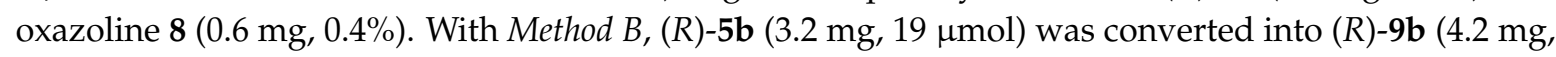
$54 \%$ yield) after purification by pipette column (silica, $20 \%$ EtOAc-hexane).

Mono-Naphthamide 7b: Recrystallized from $\mathrm{CDCl}_{3}$, m.p. $135{ }^{\circ} \mathrm{C} ;[\alpha]_{\mathrm{D}}^{23}-5.7(c 0.98, \mathrm{MeOH}) ;{ }^{1} \mathrm{H}$ NMR $\left(\mathrm{CDCl}_{3}, 500 \mathrm{MHz}\right) \delta 8.29\left(\mathrm{~s}, 1 \mathrm{H}, \mathrm{H}-1^{\prime}\right), 7.88-7.81(\mathrm{~m}, 4 \mathrm{H}), 6.91(\mathrm{bt}, 1 \mathrm{H}, \mathrm{NH}), 3.85(\mathrm{~m}, 1 \mathrm{H}, \mathrm{H}-2), 3.76(\mathrm{ddd}$, $1 \mathrm{H}, J=13.5,7.0,3.0 \mathrm{~Hz}, \mathrm{H}-1 \mathrm{a}), 3.45(\mathrm{ddd}, 1 \mathrm{H}, J=13.5,8.0,5.0 \mathrm{~Hz}, \mathrm{H}-1 \mathrm{~b}), 2.84(\mathrm{bs}, 1 \mathrm{H}, \mathrm{OH}), 1.53(\mathrm{~m}, 2 \mathrm{H})$, $1.44(\mathrm{~m}, 1 \mathrm{H}), 1.34(3 \mathrm{H}), 0.90\left(\mathrm{t}, 3 \mathrm{H}, J=7.0 \mathrm{~Hz}, \mathrm{H}_{3}-6\right) .{ }^{13} \mathrm{C} \mathrm{NMR}\left(\mathrm{CDCl}_{3},{ }^{*}=\right.$ interchangeable $) 168.6(\mathrm{C}$, $\mathrm{C}=\mathrm{O}), 134.9\left(\mathrm{C}, \mathrm{C}-2^{\prime *}\right), 132.7\left(\mathrm{C}, \mathrm{C}-4 \mathrm{a}^{*}\right), 131.5\left(\mathrm{C}, \mathrm{C} 8 \mathrm{a}^{*}\right), 129.0(\mathrm{CH}), 128.6(\mathrm{CH}), 127.85(\mathrm{CH}), 127.82(\mathrm{CH})$, $127.7(\mathrm{CH}), 126.9(\mathrm{CH}), 123.7(\mathrm{CH}), 71.6(\mathrm{CH}, \mathrm{C}-2), 46.4\left(\mathrm{CH}_{2}, \mathrm{C}-1\right), 35.0\left(\mathrm{CH}_{2}, \mathrm{C}-3\right), 27.8\left(\mathrm{CH}_{2}, \mathrm{C}-4\right)$, $22.8\left(\mathrm{CH}_{2}, \mathrm{C}-5\right), 14.2\left(\mathrm{CH}_{2}, \mathrm{C}-6\right)$; ESI TOF HRMS $m / z 294.1468[\mathrm{M}+\mathrm{Na}]^{+}$calcd. for $\mathrm{C}_{17} \mathrm{H}_{21} \mathrm{NO}_{2} \mathrm{Na}^{+}$ 294.1465.

Oxazoline 8: $[\alpha]_{\mathrm{D}}^{23}+2.6\left(\right.$ c 0.50, $\left.\mathrm{CHCl}_{3}\right) ;{ }^{1} \mathrm{H} \mathrm{NMR}\left(\mathrm{CDCl}_{3}, 500 \mathrm{MHz}\right) \delta 8.43\left(\mathrm{bd}, 1 \mathrm{H}, J=1.5 \mathrm{~Hz}, \mathrm{H}-1^{\prime}\right)$, $8.03\left(\mathrm{dd}, 1 \mathrm{H}, J=8.5,1.5 \mathrm{~Hz}, \mathrm{H}-3^{\prime}\right), 7.92\left(\mathrm{~d}, 1 \mathrm{H}, J=7.5 \mathrm{~Hz}, \mathrm{H}-8^{\prime}\right), 7.87-7.86(\mathrm{~m}, 2 \mathrm{H})$, 7.57-7.7.50 (m, 2H); ESI TOF HRMS $m / z 254.1539[\mathrm{M}+\mathrm{H}]^{+}$, calcd. for $\mathrm{C}_{17} \mathrm{H}_{20} \mathrm{NO}^{+} 254.1539$.

N,O-di-(2-Naphthoyl)-1-amino-2-hexanol (R)-9b: Colorless oil, $[\alpha]_{\mathrm{D}}^{23}-67$ (c 0.8, TFE); ECD (TFE) $\delta 228$ $(\Delta \varepsilon+53), 236(0), 244(-66) ;{ }^{1} \mathrm{H}$ NMR $\left(\mathrm{CDCl}_{3}, 500 \mathrm{MHz}\right) \delta 8.65\left(\mathrm{~s}, 1 \mathrm{H}, \mathrm{H}-1^{\prime}\right), 8.27\left(\mathrm{~s}, 1 \mathrm{H}, \mathrm{H}-1^{\prime \prime}\right), 8.09$ (d, $\left.1 \mathrm{H}, J=8.5 \mathrm{~Hz}, \mathrm{H}-3^{\prime}\right), 7.97\left(\mathrm{~d}, 1 \mathrm{H}, J=8.0 \mathrm{~Hz}, \mathrm{H}-3^{\prime \prime}\right), 7.91(\mathrm{~m}, 6 \mathrm{H}), 7.79(\mathrm{~d}, 1 \mathrm{H}, J=8.5 \mathrm{~Hz}), 7.62-7.50(\mathrm{~m}$, $4 \mathrm{H}), 6.92(\mathrm{bt}, 1 \mathrm{H}, J=5.0 \mathrm{~Hz}, \mathrm{NH}), 5.42(\mathrm{~m}, 1 \mathrm{H}, \mathrm{H}-2), 3.91(\mathrm{ddd}, 1 \mathrm{H}, J=14.5,5.0,3.5 \mathrm{~Hz}, \mathrm{H}-1 \mathrm{a}), 3.85$ (ddd, 1H, $J=14.5,9.0,5.0 \mathrm{~Hz}, \mathrm{H}-1 \mathrm{~b}), 1.92(\mathrm{~m}, 1 \mathrm{H}, \mathrm{H}-3 \mathrm{a}), 1.84(\mathrm{~m}, 1 \mathrm{H}, \mathrm{H}-3 \mathrm{~b}), 1.5\left(\mathrm{~m}, 2 \mathrm{H}, \mathrm{H}_{2}-4\right), 1.42(\mathrm{~m}$, $\left.2 \mathrm{H}, \mathrm{H}_{2}-5\right), 0.94\left(\mathrm{t}, 3 \mathrm{H}, J=7.3 \mathrm{~Hz}, \mathrm{H}_{3}-6\right)$; ESI TOF HRMS $m / z$ 426.2061 $[\mathrm{M}+\mathrm{H}]^{+}$calcd. for $\mathrm{C}_{28} \mathrm{H}_{28} \mathrm{NO}_{3}{ }^{+}$ 426.2064 .

Tribenzoyl-1-amino-butanol (S)-10a: A solution of 1-AA (S)-6a (66.7 mg, $0.75 \mathrm{mmol})$ in dry pyridine $(2.0 \mathrm{mg})$ and DMAP (1 crystal) was treated with freshly distilled benzoyl chloride $(271 \mu \mathrm{L}, 2.99 \mathrm{mmol})$ and the mixture heated at $60{ }^{\circ} \mathrm{C}$ under at atmosphere of $\mathrm{N}_{2}$ with stirring for $48 \mathrm{~h}$. The volatiles were removed under high vacuum and the semi-crystalline residue (1.28 g) taken up in $\mathrm{CH}_{2} \mathrm{Cl}_{2}$ and filtered through a plug of basic alumina. The eluate was concentrated and the residue separated on a pencil column' (silica, elution with 1:4 EtOAc/n-hexane) to give a non-polar, clear oil (67 mg) that was further purified by HPLC (silica, $10 \times 250 \mathrm{~mm}, 5 \mu, 1: 4 \mathrm{EtOAc} / n$-hexane) to give tribenzoyl derivative (S)-10b 
(14.9 mg, 5\%). $[\alpha]_{\mathrm{D}}^{22}+44.6\left(\right.$ c 2.92, MeOH); ${ }^{1} \mathrm{H} \mathrm{NMR}\left(\mathrm{CDCl}_{3}, 500 \mathrm{MHz}\right) \delta 7.81\left(\mathrm{~d}, 2 \mathrm{H}, J=7.5 \mathrm{~Hz}, \mathrm{H}-2^{\prime \prime}, 6^{\prime \prime}\right)$, $7.39\left(\mathrm{t}, 1 \mathrm{H}, J=7.4 \mathrm{~Hz}, \mathrm{H}-4^{\prime \prime}\right), 7.33\left(\mathrm{~d}, 4 \mathrm{H}, J=7.5 \mathrm{~Hz}, \mathrm{H}-2^{\prime}, 6^{\prime}\right), 7.23\left(\mathrm{t}, 2 \mathrm{H}, J=7.5 \mathrm{~Hz}, \mathrm{H}-3^{\prime \prime}, 5^{\prime \prime}\right), 7.12(\mathrm{t}, 2 \mathrm{H}$, $\left.J=7.5 \mathrm{~Hz}, \mathrm{H}-4^{\prime}\right), 7.02\left(\mathrm{t}, 4 \mathrm{H}, J=7.5 \mathrm{~Hz}, \mathrm{H}-3^{\prime}, 5^{\prime}\right), 5.65(\mathrm{~m}, 1 \mathrm{H}, \mathrm{H}-2), 4.53(\mathrm{dd}, 1 \mathrm{H}, J=14.0,9.1 \mathrm{~Hz}, \mathrm{H}-1 \mathrm{a})$, $4.25(\mathrm{dd}, 1 \mathrm{H}, J=14.1,2.8 \mathrm{~Hz}, \mathrm{H}-1 \mathrm{~b}), 1.87\left(\mathrm{~m}, 2 \mathrm{H}, \mathrm{H}_{2}-3\right), 1.06\left(\mathrm{t}, 3 \mathrm{H}, J=7.5 \mathrm{~Hz}, \mathrm{H}_{3}-6\right) .{ }^{13} \mathrm{C} \mathrm{NMR}_{\left(\mathrm{CDCl}_{3}\right)}$ $\delta\left(\mathrm{C}, \mathrm{N}(\mathrm{C}=\mathrm{O})_{2}\right), 166.4(\mathrm{C}, \mathrm{O}(\mathrm{C}=\mathrm{O})), 136.3\left(\mathrm{C}, \mathrm{C}_{2}-1^{\prime}\right), 132.8\left(\mathrm{CH}, \mathrm{C}-4^{\prime \prime}\right), 131.9\left(\mathrm{C}, \mathrm{C}_{2}-4^{\prime}\right), 130.0\left(\mathrm{CH}, \mathrm{C}-1^{\prime \prime}\right)$, $129.6\left(\mathrm{CH}, \mathrm{C}-2^{\prime}, 6^{\prime}\right), 129.0\left(\mathrm{CH}, \mathrm{C}_{4}-2^{\prime}, 6^{\prime}\right), 128.16\left(\mathrm{CH}, \mathrm{C}_{2}-3^{\prime}\right), 128.15\left(\mathrm{CH}, \mathrm{C}-3^{\prime \prime}\right), 75.0(\mathrm{CH}, \mathrm{C}-2), 49.9$ $\left(\mathrm{CH}_{2}, \mathrm{C}-1\right), 25.8\left(\mathrm{CH}_{2}, \mathrm{C}-3\right), 9.6\left(\mathrm{CH}_{3}, \mathrm{C}-4\right)$; HRMS $m / z 424.1520[\mathrm{M}+\mathrm{Na}]^{+}$, calcd. for $\mathrm{C}_{25} \mathrm{H}_{23} \mathrm{NO}_{4} \mathrm{Na}^{+}$ 424.1519 .

Naphthimide (R)-11b: A solution of the 1-AA $(R)-5 \mathbf{b}(3.5 \mathrm{mg}, 30.3 \mu \mathrm{mol})$ in dry pyridine $(0.175 \mathrm{~mL})$ was added to a stirred solution of freshly sublimed 2,3-naphthalenedicarboxylic acid anhydride $(9.0 \mathrm{mg}$, $45.4 \mu \mathrm{mol}, 1.5$ equiv.) in dry pyridine $(0.325 \mathrm{~mL})$ and the mixture heated to $110{ }^{\circ} \mathrm{C}$ under $\mathrm{N}_{2}$ for $48 \mathrm{~h}$. The volatiles were removed under a stream of $\mathrm{N}_{2}$. The residue was divided in half, and each applied to duplicate preparative TLC plates (silica, $200 \times 200 \times 0.25 \mathrm{~mm}$ ). The plates were developed, twice (2:3 EtOAc $/ n$-hexane) and the silica corresponding to the major fluorescent bands (TLC, $R_{\mathrm{f}}=0.52$, 1:1 EtOAc/ $n$-hexane) were scrapped from the plates and extracted with EtOAc. The extracts were combined, filtered and the solvent removed from the filtrate to deliver $(R)-\mathbf{1 1 b}(6.9 \mathrm{mg}, \mathbf{7 4} \%)$ as a colorless powder. $[\alpha]_{\mathrm{D}}^{22}+7.0\left(c 0.64, \mathrm{CHCl}_{3}\right) ;{ }^{1} \mathrm{H} \mathrm{NMR}\left(\mathrm{CDCl}_{3}, 500 \mathrm{MHz}\right) \delta 8.35\left(\mathrm{~s}, 2 \mathrm{H}, \mathrm{H}-1^{\prime}, 4^{\prime}\right), 8.05(\mathrm{~m}$, $\left.2 \mathrm{H}, \mathrm{H}-5^{\prime}, 6^{\prime}\right), 7.71\left(\mathrm{~m}, 2 \mathrm{H}, \mathrm{H}-7^{\prime}, 8^{\prime}\right), 3.94(\mathrm{~m}, 1 \mathrm{H}, \mathrm{H}-2), 3.88(\mathrm{dd}, 1 \mathrm{H}, J=14.0,3.5 \mathrm{~Hz}, \mathrm{H}-1 \mathrm{a}), 3.82(\mathrm{dd}, 1 \mathrm{H}$, $J=14.0,8.0 \mathrm{~Hz}, \mathrm{H}-1 \mathrm{~b}), 2.46(\mathrm{bs}, 1 \mathrm{H}, \mathrm{OH}), 1.58-1.48\left(\mathrm{~m}, 2 \mathrm{H}, \mathrm{H}_{2}-3\right), 1.42-1.33\left(\mathrm{~m}, 4 \mathrm{H}, \mathrm{H}_{2}-4, \mathrm{H}_{2}-5\right), 0.92$ (t, $\left.3 \mathrm{H}, J=7.0 \mathrm{~Hz}, \mathrm{H}_{3}-6\right)$; ESI TOF HRMS $m / z 320.1253[\mathrm{M}+\mathrm{Na}]^{+}$, calcd. for $\mathrm{C}_{18} \mathrm{H}_{19} \mathrm{NO}_{3} \mathrm{Na}^{+}$320.1257.

O-Naphthoyl-naphthimide (R)-12b: An ice-cold solution of 2-naphthoic acid (4.0 mg, $32 \mu \mathrm{mol}, 5.0$ equiv.), DMAP ( $4.0 \mathrm{mg}$, $33 \mu \mathrm{mol}$, 5.1 equiv.) and $\mathrm{EDC} \cdot \mathrm{HCl}\left(6.3 \mathrm{mg}, 33 \mu \mathrm{mol}\right.$, 5.1 equiv.) in $\mathrm{CH}_{2} \mathrm{Cl}_{2}(0.5 \mathrm{~mL})$ was stirred for $30 \mathrm{~min}$ under an atmosphere of $\mathrm{N}_{2}$, then treated with a solution of naphthimide $(R)-\mathbf{1 1} \mathbf{b}$ ( $2.2 \mathrm{mg}, 6.4 \mu \mathrm{mol})$ in $\mathrm{CH}_{2} \mathrm{Cl}_{2}(0.3 \mathrm{~mL})$. The solution was allowed to warm to $23^{\circ} \mathrm{C}$ and stirred for $64 \mathrm{~h}$, then diluted with additional $\mathrm{CH}_{2} \mathrm{Cl}_{2}(15 \mathrm{~mL})$ and washed sequentially with $0.2 \mathrm{M} \mathrm{HCl}, \mathrm{NaHCO}_{3}$ (satd.) and water. After drying the solution $\left(\mathrm{Na}_{2} \mathrm{SO}_{4}\right)$, the volatiles were removed and the residue $(4.5 \mathrm{mg})$ purified by 'pencil column' chromatography (silica, 1:4 EtOAc/ $n$-hexane) to give pure $(R)-\mathbf{1 2} \mathbf{b}$ as a colorless oil ( $2.2 \mathrm{mg}, 72 \%, R_{\mathrm{f}} 0.20,1: 4 \mathrm{EtOAc} / n$-hexane). $[\alpha]_{\mathrm{D}}^{22}-90(c 0.44, \mathrm{TFE}) ; \mathrm{ECD}$ (TFE) $\delta 216(\Delta \varepsilon$ +24.7), 240 (+25.8), $245(0), 259(-31.8) ;{ }^{1} \mathrm{H} \mathrm{NMR}\left(\mathrm{CDCl}_{3}, 500 \mathrm{MHz},{ }^{*}=\right.$ interchangeable) $\delta 8.55(\mathrm{~d}, 1 \mathrm{H}$, $\left.J=1.4 \mathrm{~Hz}, \mathrm{H}-1^{\prime \prime}\right), 8.29\left(\mathrm{~s}, 2 \mathrm{H}, \mathrm{H}_{2}-1^{\prime}, 4^{\prime}\right), 8.00\left(\mathrm{~m}, 2 \mathrm{H}, \mathrm{H}_{2}-5^{\prime \prime}, 8^{\prime \prime}\right), 7.98\left(\mathrm{dd}, 1 \mathrm{H}, J=8.3,1.4 \mathrm{~Hz}, \mathrm{H}-3^{\prime \prime}\right), 7.94$ $(\mathrm{d}, 1 \mathrm{H}, J=8.0 \mathrm{~Hz}), 7.85(\mathrm{~d}, 1 \mathrm{H}, J=7.0 \mathrm{~Hz}), 7.83(\mathrm{~d}, 1 \mathrm{H}, J=8.5 \mathrm{~Hz}), 7.85(\mathrm{dd}, 1 \mathrm{H}, J=7.7,0.8 \mathrm{~Hz}), 7.83(\mathrm{~d}$, $J=8.3 \mathrm{~Hz}), 7.66\left(\mathrm{~m}, 2 \mathrm{H}, \mathrm{H}-6^{\prime}, 7^{\prime}\right), 7.57\left(\mathrm{td}, 1 \mathrm{H}, J=7.5,1.5 \mathrm{~Hz}, \mathrm{H}-6^{\prime \prime *}\right), 7.52\left(\mathrm{td}, 1 \mathrm{H}, J=7.5,1.0 \mathrm{~Hz}, \mathrm{H}-7^{\prime \prime *}\right)$, $5.52(\mathrm{~m}, 1 \mathrm{H}, \mathrm{H}-2), 4.16(\mathrm{dd}, 1 \mathrm{H}, J=14.0,8.5 \mathrm{~Hz}, \mathrm{H}-1 \mathrm{a}), 4.02(\mathrm{dd}, 1 \mathrm{H}, J=14.0,3.0 \mathrm{~Hz}, \mathrm{H}-1 \mathrm{~b}), 1.85(\mathrm{~m}$, $\left.2 \mathrm{H}, \mathrm{H}_{2}-3\right), 1.49\left(\mathrm{~m}, 2 \mathrm{H}, \mathrm{H}_{2}-4\right), 1.40\left(\mathrm{~m}, 2 \mathrm{H}, \mathrm{H}_{2}-5\right), 0.92\left(\mathrm{t}, 3 \mathrm{H}, J=7.3 \mathrm{~Hz}, \mathrm{H}_{3}-6\right)$; ESI TOF HRMS $m / z$ $452.1847[\mathrm{M}+\mathrm{H}]^{+}$, calcd. for $\mathrm{C}_{29} \mathrm{H}_{26} \mathrm{NO}_{4}{ }^{+} 452.1856$.

N,O-di-(2-Naphthoyl)-1-amino-2-decanol (S)-13a: A sample of the 1-AA (S)-3a (4.5 mg, $16 \mu \mathrm{mol})$ was acylated with 2-naphthoic acid (5 equiv.) using Method $B$ to give, after standard workup and purification by pipette column (silica, 1:5 $n$-hexane $\left./ \mathrm{CH}_{2} \mathrm{Cl}_{2}\right), \mathbf{1 3 a}(3.5 \mathrm{mg}, 46 \%)$. $\left.[\alpha]_{\mathrm{D}}^{20}+94\left(c, 0.16, \mathrm{CHCl}_{3}\right)\right)$, which displayed ${ }^{1} \mathrm{H}$ and ${ }^{13} \mathrm{C}$ NMR spectra identical with those of (R)-13b [12]. ESI TOF HRMS $m / z$ 504.2501 $[\mathrm{M}+\mathrm{Na}]^{+}$, calcd. for $\mathrm{C}_{32} \mathrm{H}_{35} \mathrm{NaNO}_{3}{ }^{+} 504.2509$.

\section{Conclusions}

An optimized approach to assignment of absolute configuration of 1-amino-2-alkanols (1-AAs), based on ECD, is presented which avoids problems with prior methods, and streamlines analyses of multiple samples. Comparison and contrast of two methods for chiroptical analysis of 1-AAs-ECD and CDA derivatization- ${ }^{1} \mathrm{H}-\mathrm{NMR}$ - revealed complementary advantages. An optimized $\mathrm{N}, \mathrm{O}$-dinaphthoyl 1-AA derivative lends clarity of interpretation of ECD spectra with sufficient sensitivity for 'sub-nanomole scale' stereoassignments. Chiroptical investigations of multiple samples of the 1-AA, distaminolyne A (1a) extracted from Pseudodistoma spp., showed that configuration and 
enantiomeric purity varied with collections, a behavior that is unlike 2-AA natural products that, so far, have been found to be stereochemically homogenous. A promiscuous biosynthesis for $1 \mathbf{a}$ is proposed to account for the difference.

Supplementary Materials: The following are available online. ${ }^{1} \mathrm{H}$ and ${ }^{13} \mathrm{C}-\mathrm{NMR}$ spectra and HRMS spectra for $(R)-\mathbf{5} \mathbf{b},(S)-\mathbf{6} \mathbf{a},(R)-\mathbf{7} \mathbf{b}, \mathbf{8},(R)-\mathbf{- 9} \mathbf{b},(S)-\mathbf{1 0} \mathbf{a},(R)-\mathbf{1 1} \mathbf{b},(R)-\mathbf{1 2} \mathbf{b}$, and $(S)-\mathbf{1 3} \mathbf{a},{ }^{1} \mathrm{H}-\mathrm{NMR}$ spectra of MPA derivatives $\mathbf{1} \mathbf{c}, \mathbf{d}$ of partially of racemic 1a, and MPA derivative of $(S)$-13a.

Author Contributions: T.F.M and B.R.C conceived of the experimental design; A.N.P. and T.F.M. carried out the experiments; and all co-authors contributed to writing the manuscript.

Funding: This research was funded by NIH AT009783-01 (to T.F.M) and part-funded by New Zealand Foundation for Research Science and Technology, contract CO1X0205 (to B.R.C)

Acknowledgments: We thank M. N. Salib for measurements of NMR spectra, A. Mrse and B. M. Duggan (UCSD) and M. Schmitz (UoA) for assistance with NMR, and Y. Su (UCSD) and T. Chen (UoA) for HRMS measurements, Richard Taylor (Leigh Lab) for collection of P. opacum samples and Mike Page (NIWA) for collection of P. cereum samples and for taxonomic identification of all ascidian specimens.

Conflicts of Interest: The author declares no conflicts of interest.

\section{References}

1. Pruett, S.T.; Bushnev, A.; Hagedorn, K.; Adiga, M.; Haynes, C.A.; Sullards, M.C.; Liotta, D.C.; Merrill, A.H. Thematic Review Series: Sphingolipids. Biodiversity of sphingoid bases ("sphingosines") and related amino alcohols. J. Lipid Res. 2008, 49, 1621-1639. [CrossRef] [PubMed]

2. Skepper, C.K.; Molinski, T.F. Long-Chain 2H-Azirines with Heterogeneous Terminal Halogenation from the Marine Sponge Dysidea fragilis. J. Org. Chem. 2008, 73, 2592-2597. [CrossRef] [PubMed]

3. Cuardos, R.; Montejo de Garcini, E.; Wandosell, F.; Faircloth, G.; Fernández-Sousa, J.M.; Avila, J. The marine compound spisulosine, an inhibitor of cell proliferation, promotes the disassembly of actin stress fibers. Cancer Lett. 2000, 152, 23-29. [CrossRef]

4. Gulavita, N.K.; Scheuer, P.J. Two Epimeric Amino Alcohols from a Sponge, Xestospongia sp. J. Org. Chem. 1989, 54, 366-369. [CrossRef]

5. Ichihashi, M.; Mori, K. Determination of the Absolute Configuration of (+)-Xestoaminol C [(2S,3R)-2-Amino3-tetradecanol], a Metabolite of Fiji Sponge, Xestospongia sp., by the Synthesis of Its N,O-Diacetyl Derivative. Biosci. Biotechnol. Biochem. 2003, 67, 329-333. [CrossRef]

6. Mori, K.; Matsuda, H. Synthesis of Sphingosine Relatives, XII Synthesis and Absolute Configuration of the Two Epimeric Aliphatic Amino Alcohols [5E, 7E)-2-Amino-5,7-tetradecadien-3-ols] Isolated from a Sponge, Xestospongia sp. Liebigs Ann. 1992, 1992, 131-137. [CrossRef]

7. Wang, J.; Pearce, A.N.; Chan, S.T.S.; Taylor, R.B.; Page, M.J.; Valentin, A.; Bourguet-Kondracki, M.-L.; Dalton, J.P.; Wiles, S.; Copp, B.R. Biologically Active Acetylenic Amino Alcohol and N-Hydroxylated 1,2,3,4-Tetrahydro- $\beta$-carboline Constituents of the New Zealand Ascidian Pseudodistoma opacum. J. Nat. Prod. 2016, 79, 607-610. [CrossRef]

8. Harada, N.; Nakanishi, K. Circular Dichroic Spectroscopy. In Exciton Coupling in Organic Stereochemistry; University Science Books: Mill Valley, CA, USA, 1983.

9. Searle, P.A.; Molinski, T.F. Structure and absolute configuration of $(R)-(\mathrm{E})-1$-aminotridec-5-en-2-ol, an antifungal amino alcohol from the ascidian Didemnum sp. J. Org. Chem. 1993, 58, 7578-7580. [CrossRef]

10. Sun, D.-Y.; Han, G.-Y.; Gong, J.-X.; Nay, B.; Li, X.-W.; Guo, Y.-W. Asymmetric Total Synthesis of Distaminolyne A and Revision of Its Absolute Configuration. Org. Lett. 2017, 19, 714-717. [CrossRef]

11. Dumpala, M.; Theegala, S.; Palakodety, R.K. Total synthesis of distaminolyne A. Tetrahedron Lett. 2017, 58, 1273-1275. [CrossRef]

12. Molinski, T.F.; Salib, M.N.; Pearce, A.N.; Copp, B.R. The Configuration of (-)-Distaminolyne A is S. Quantitative Evaluation of Exciton Coupling Circular Dichroism of N,O-bis-Arenoyl-1-amino-2-alkanols. J. Nat. Prod. under review.

13. Ikemoto, N.; Lo, L.-C.; Nakanishi, K. Detection of Subpicomole Levels of Compounds Containing Hydroxyl and Amino Groups with the Fluorogenic Reagent, 2-Naphthoylimidazole. Angew. Chem. Int. Ed. 1992, 31, 890-891. [CrossRef] 
14. Kossuga, M.H.; MacMillan, J.B.; Rogers, E.W.; Molinski, T.F.; Nascimento, G.G.F.; Rocha, R.M.; Berlinck, R.G.S. (2S,3R)-2-Aminododecan-3-ol, a New Antifungal Agent from the Ascidian Clavelina oblonga. J. Nat. Prod. 2004, 67, 1879-1881. [CrossRef]

15. Molinski, T.F.; Biegelmeyer, R.; Stout, E.P.; Wang, X.; Frota, M.L.C.; Henriques, A.T. Halisphingosines A and B, Modified Sphingoid Bases from Haliclona tubifera. Assignment of Configuration by Circular Dichroism and van't Hoff's Principle of Optical Superposition. J. Nat. Prod. 2013, 76, 374-381. [CrossRef] [PubMed]

16. Mikno, S.D.; Filippova, T.M.; Kulachkina, N.S.; Polyanskaya, T.N.; Kustanovich, I.M.; Berezovskiii, V.M. Studey of the Inversion of 4-Benzamido-3-hydroxythiophane. Khim. Geterotsiklicheskikh Soedin. 1971, 7, 1339-1344.

17. Palmer, D.C. (Ed.) Oxazoles: Synthesis, Reactions and Spectroscopy, Part B; Heterocyclic Compounds; Wiley: Hoboken, NJ, USA, 2004; Volume 60.

18. Kawamura, A.; Berova, N.; Dirsch, V.; Mangoni, A.; Nakanishi, K.; Schwartz, G.; Bielawska, A.; Hannun, Y.; Kitagawa, I. Picomole scale stereochemical analysis of sphingosines and dihydrosphingosines. Bioorg. Med. Chem. 1996, 4, 1035-1043. [CrossRef]

19. Dirsch, V.; Frederico, J.; Ning, Z.; Guolin, C.; Yanqui, C.; Vunnam, S.; Odingo, J.; Hyan, P.; Nakanishi, K.; Berova, N.; et al. A two-step chemical and circular dichroic method for assigning the absolute configurations of sphingosines. Tetrahedron Lett. 1995, 36, 4959-4962. [CrossRef]

20. Seco, J.M.; Quiñoá, E.; Riguera, R. Assignment of the Absolute Configuration of Polyfunctional Compounds by NMR Using Chiral Derivatizing Agents. Chem. Rev. 2012, 112, 4603-4641. [CrossRef]

21. Kawai, M.; Nagai, U.; Katsumi, M. CD-spectra of $N, N^{\prime}$-dibenzoylamino acids and related compounds: Evidence for the conformation of acyclic diamino compounds. Tetrahedron Lett. 1975, 16, 3165-3166. [CrossRef]

22. Du, L.; Zhu, X.; Gerber, R.; Huffman, J.; Lou, L.; Jorgenson, J.; Yu, F.; Zaleta-Rivera, K.; Wang, Q. Biosynthesis of sphinganine-analog mycotoxins. J. Ind. Microbiol. Biotechnol. 2008, 35, 455-464. [CrossRef]

23. Nicholas, G.M.; Molinski, T.F. Enantiodivergent Biosynthesis of the Dimeric Sphingolipid Oceanapiside from the Marine Sponge Oceanapia phillipensis. Determination of Remote Stereochemistry. J. Am. Chem. Soc. 2000, 122, 4011-4019. [CrossRef]

24. Tokunaga, M.; Larrow, J.F.; Kakiuchi, F.; Jacobsen, E.N. Asymmetric Catalysis with Water: Efficient Kinetic Resolution of Terminal Epoxides by Means of Catalytic Hydrolysis. Science 1997, 277, 936-938. [CrossRef] [PubMed]

25. Mullen, L.B.; Sutherland, J.D. Formation of Potentially Prebiotic Amphiphiles by Reaction of $\beta$-Hydroxy- $n$-alkylamines with Cyclotriphosphate. Angew. Chem. Int. Ed. 2007, 46, 4166-4168. [CrossRef] [PubMed]

26. Hodgson, D.M.; Humphreys, P.G.; Xu, Z.; Ward, J.G. Lithiation-Induced Migrations from Nitrogen to Carbon in Terminal Aziridines. Angew. Chem. Int. Ed. 2007, 46, 2245-2248. [CrossRef] [PubMed]

Sample Availability: Samples of compounds are not available from the authors.

(C) 2018 by the authors. Licensee MDPI, Basel, Switzerland. This article is an open access article distributed under the terms and conditions of the Creative Commons Attribution (CC BY) license (http:/ / creativecommons.org/licenses/by/4.0/). 